\title{
AKAD WAKÂLAHDAN SAMSARAH SEBAGAI SOLUSI ATAS KLAIM KEHARAMAN DROPSHIP DALAM JUAL BELI ONLINE
}

\author{
Ika Yunia Fauzia \\ Sekolah Tinggi Ilmu Ekonomi Perbanas Surabaya, Indonesia \\ E-mail: ika.yunia@perbanas.ac.id
}

\begin{abstract}
Online business (selling-buying) has become prominent in the past few years ago as demand increases. This kind of business forms a positive effect of the development of internet which produces new business-men. Along with the development of online business, there emerges dropship system which is mostly undertaken by female entrepreneurs. Despite its negative effect, dropship system has positive influence, i.e. creating positive activities for women and therefore empowering them. The polemics of dropship is still going on. According to some Muslim jurists, dropship is forbidden (ḩarâm) because the practicioners of this system sell items only from picture. Moreover, the items sold have not been the property of the practicioners. This article deals with the benefit of wakalah and samsarab contract used to accommodate the dropship system. The specification of both contracts is explained in detail in order for this system to be undertaken as wakalah and samsarah contract. The practicioners of dropship as wakil, and suppliers as muwakkil, or the practicioners of dropship as simsâr with some conditions that should be accorded to the contract in the beginning of transaction.
\end{abstract}

Keywords: Online business; dropship; wakâlah; samsarah.

\section{Pendahuluan}

Jual beli online merupakan ceruk baru dalam pemasaran dikarenakan banyaknya kemudahan-kemudahan yang bisa dijumpai seorang penjual dalam memasarkan produk atau jasa yang dimilikinya. Dalam bisnis online seorang penjual dan pembeli tidak harus bertemu di suatu tempat untuk bertransaksi, dan dalam hitungan detik transaksi bisa langsung terjadi. Bisnis online memunculkan pembeli yang cerdas dikarenakan pembeli bisa dengan leluasa membanding- 
bandingkan harga sebuah produk atau jasa tanpa berpindah dari suatu tempat ke tempat yang lainnya, sehingga seorang pembeli tidak lagi memikirkan waktu yang terbuang untuk berbelanja ke sebuah pusat perbelanjaan, jalanan yang macet, tempat parkir mobil yang penuh dan lain sebagainya.

Ketika melihat ke belakang, beberapa dasawarsa terakhir tidak banyak di antara masyarakat yang mengerti istilah internet marketing, business online, e-commerce, online shop, online gallery, affiliate marketing, dan beberapa istilah lainnya yang terkait dengan bisnis yang dijalankan melalui media internet ataupun online. Penjualan ataupun pembelian barang atau jasa semakin merebak dan diikuti dengan meningkatnya jumlah pemain industri bisnis online. Transaksi dengan media internet berkembang seiring dengan semakin meningkatnya pengguna internet. Hal tersebut kemudian memunculkan asosiasi di kalangan pelaku ecommerce, ${ }^{1}$ dengan dibentuknya sebuah organisasi yang bernama "Indonesian E-Commerce Association atau Asosiasi E-Commerce Indonesia (IDEA/www.idea.or.id)". Di antara para pelaku e-commerce yang telah mendapatkan hati di masyarakat antara lain tokobagus.com, tokopedia.com, zalora.com, multiply.com, bhineka.com, blibli.com, dealgoing.com, gramedia.com, kaskus.us, olx.co.id, dan masih banyak lagi yang lainnya. Bertambahnya jumlah pengusaha bisnis online bukan tanpa alasan, jumlah peningkatan pengguna internet merupakan sebab yang kuat, bisnis online melesat cepat dengan demand yang sangat tinggi, ${ }^{2}$ sehingga bisa ditemukan di semua kalangan, baik di pedesaan maupun di perkotaan bisnis dengan sistem online bisa tumbuh dengan

\footnotetext{
${ }^{1}$ Electronic commerce (e-commerce) adalah proses pembelian, penjualan atau pertukaran produk, jasa dan informasi melalui jaringan komputer. E-commerce merupakan bagian dari e-business, di mana cakupan e-business lebih luas, tidak hanya mencakup perniagaan tetapi juga mencakup pengkolaborasian mitra bisnis, pelayanan nasabah, lowongan pekerjaan, dan lain-lain. Selain teknologi jaringan melalui www.e-commerce juga memerlukan teknologi basis data atau pangkalan data (database), e-surat atau surat elektronik (e-mail), dan bentuk teknologi non komputer yang lain seperti halnya sistem pengiriman barang dan alat pembayaran untuk e-commerce ini. Ecommerce merupakan proses mencari pelanggan, pemasok dan mitra usaha secara digital dari luar (eksternal) dengan menggunakan website atau media internet lainnya, sedangkan e-business meliputi bagaimana proses di dalam tubuh organisasi bisnis tersebut (internal). Lihat Ika Yunia Fauzia, Pemanfaatan E-Commerce dan $M$ Commerce dalam Bisnis di Kalangan Wirausahawan Perempuan (Surabaya: STIE Perbanas, 2015), 3.

2 Ika Yunia Fauzia, Transcendental Trust dalam Bisnis Online di Kalangan Pengusaba Garment di Indonesia (Surabaya: Penelitian Internal STIE Perbanas, 2015), 3.
} 
subur, yang juga menciptakan ceruk baru bagi industri ekspedisi karena banyaknya permintaan jasa antar barang.

Berdasarkan survei yang dilakukan Nielsen pada 2011, pengguna internet via mobile di Indonesia adalah yang tertinggi bila dibandingkan dengan negara Asia Timur lainnya, yaitu mencapai 41 persen. Hal ini menandakan bahwa Indonesia merupakan sebuah potensi pasar yang luar biasa, baik bagi pemilik bisnis maupun bagi calon pemilik bisnis, untuk merambah ke dunia maya sebagai salah satu marketing tools-nya. Bisa dibayangkan berapa banyak demand penduduk Indonesia untuk bisnis online jika pengguna internet via mobile mencakup $41 \%$ dari jumlah penduduk Indonesia. Jika potensi tersebut digali dengan sangat baik, maka bukan menjadi suatu hal yang mustahil produkproduk dalam negeri akan sangat mudah dipasarkan dan mempunyai konsumen yang loyal di dalam dan luar negeri.

Di beberapa kesempatan, pemerintah daerah juga banyak menyosialisasikan bisnis online untuk mengembangkan jangkauan pemasaran usaha kecil, sehingga banyak ditemukan perajin yang menggunakan internet sebagai alat untuk memasarkan usaha mereka. Demand mereka bertambah karena luasnya jangkauan pemasaran dan omzet mereka pun merangkak naik ke atas.

Salah satu contoh kegiatan yang diadakan oleh pemerintah kota Surabaya melalui Badan Koordinasi Pelayanan dan Penanaman Modal (PKPPM), yaitu menggandeng Rakuten (Perusahaan e-commerce asal Jepang) untuk menjadi mitra bagi Usaha Mikro Kecil Menengah (UMKM) yang ingin mengembangkan diri. Direktur Rakuten Belanja Online, Yasunabu Hashimoto menjelaskan kepada para wartawan di Nur Pacific Surabaya, dirinya ingin agar UMKM di Surabaya melakukan transformasi bisnis dari offline menuju online, serta memaksimalisir penggunaan e-commerce untuk meningkatkan usaha mereka. Yasunabu berkeinginan agar 10.000 UMKM di Indonesia melek teknologi dan melihat potensi e-commerce sebagai masa depan bagi bisnis mereka. Bisnis offline mungkin saja sedang menurun tetapi bisnis online grafiknya sedang naik ke atas dan pasar e-commerce Indonesia diproyeksikan akan melebihi nilai USD 18 miliar hingga akhir 2015, namun sayang sekali kurang dari 1\% UMKM lokal yang telah memanfaatkan e-commerce untuk mengembangkan bisnis mereka. ${ }^{3}$

\footnotetext{
3 Imam Wahyudiyanta, "Dream Merchant: Cara Rakuten Online-kan UMKM di Surabaya", dalam http://news.detik.com/berita-jawa-timur/3027217/dreammerchant-cara-rakuten-online-kan-umkm-di-surabaya (Diakses 8 Februari 2015).
} 
Beberapa usaha yang dilakukan oleh pemerintah provinsi untuk meng-online-kan UMKM tergolong berhasil, di beberapa kesempatan penulis melihat banyak UMKM yang kemudian berinovasi untuk meningkatkan penjualan produknya. Misalnya, ada salah seorang penjual semanggi di salah satu daerah di Surabaya yang kemudian berinovasi menjual semanggi yang telah dikeringkan dan bumbu semanggi yang telah di-packing dengan baik. Proses untuk memakan semanggi hanya dengan direndam air panas. Ia menandaskan bahwa ide kreatif itu ia temukan setelah mengikuti pelatihan bisnis online yang difasilitasi oleh pemerintah kota Surabaya. Akhirnya, rata-rata perbulan omzetnya meningkat karena penjualan semanggi online yang dimilikinya berjalan dengan baik.

\section{Konsep Dropship dalam Bisnis Online}

Maraknya bisnis online diikuti dengan maraknya sistem dropship di dalamnya. Sebuah sistem yang sangat familiar dengan para pedagang kecil, pedagang dadakan dan seseorang yang baru ingin mencoba berdagang tetapi tidak mempunyai modal yang cukup. Dropship merupakan sebuah aktivitas di mana seseorang berjualan hanya bermodalkan sebuah gambar tanpa memiliki barang yang akan dijual. Ilustrasinya adalah seperti ini: "Andi merupakan pengusaha garmen yang menjual busana muslimah, kemudian Andi memproduksi dan memfoto beberapa busana tersebut dan memasarkannya dengan cara bisnis online. Kemudian ada beberapa reseller Andi (penjual yang ingin bergabung memasarkan produk yang dibuat oleh Andi) mengambil foto-foto yang dipasarkan oleh Andi dan reseller tersebut memasarkan kepada konsumen (hanya dengan bantuan foto). Ketika konsumen membeli produk tersebut dari reseller Andi/dropshipper, maka reseller/dropshipper tersebut memerintahkan kepada konsumen untuk membayar dengan cara transfer, reseller/dropshipper itu pun membeli dari Andi dan Andi langsung mengirimkan barang yang dibeli oleh konsumen reseller/dropshipper tersebut. Dengan cara mencantumkan bahwa nama pengirim adalah nama reseller/dropshipper Andi”. Untuk lebih jelasnya, lihat gambar di bawah ini: 


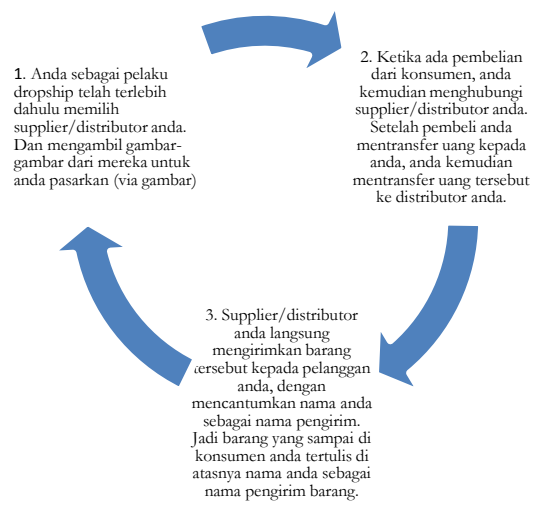

Aktivitas seperti ilustrasi di atas biasa dikenali dengan dropship. Transaksi dengan model ini mampu memicu menjamurnya perilaku dropshiping karena aktivitas ini relatif mudah dan bisa dilakukan oleh siapa saja yang ingin berjualan di kancah bisnis online tanpa mempersiapkan modal terlebih dahulu. Aktivitas ini, di satu sisi, menguntungkan banyak orang akan tetapi, di sisi lain, masih dipertanyakan keabsahannya secara sharî‘'ah. Terlebih jika dropshipping dalam menjual produk lewat gambar itu tidak mengetahui secara detail produk yang akan dijual olehnya, sehingga konsumen seringkali dirugikan karena produk riil tidak sesuai dengan gambar dan bahkan lebih buruk dari gambar.

Sebenarnya dropship memiliki beberapa kelebihan, di antaranya: 1) mampu menciptakan lapangan kerja baru, khususnya bagi ibu-ibu rumah tangga yang selama ini banyak membuang-buang waktu mereka untuk kegiatan yang tidak produktif; 2) menciptakan banyak supplier dan agen-agen penjualan baru, sehingga dengan adanya beberapa reseller, usaha mereka akan dapat bertahan dengan baik dan pada akhirnya bisa berkembang dengan kompetitif; dan 3) memanjakan konsumen karena saluran distribusi yang tidak terlalu panjang, sehingga konsumen bisa mendapatkan barang-barang yang diinginkannya tidak melalui gerai-gerai khusus bahkan seringkali dengan harga yang lebih murah dari harga pasar.

Adapun aspek negatif dari dropship di antaranya adalah kualifikasi barang yang tidak sama antara akad dan serah terima. Pemberlakuan khiyâr akan sangat sulit dikarenakan transaksi secara jarak jauh. ${ }^{4}$

4 Pemberlakuan khiyâr dalam jual beli online agaknya relatif mendekati mustabîl walaupun bisa dilakukan. Pada akhirnya jika ada pemberlakuan khiyâr, maka salah satu pihak pun akan terugikan karena ongkos kirim yang telah dibayarkan tidak akan 
Dalam beberapa kasus ditemukan bahwa antara spesifikasi gambar dengan produk riil yang sampai ke tempat customer tidak sama. Ketidaksesuaian produk dengan gambar bisa jadi dikarenakan kualitas barang yang tidak sama dengan gambar, kualitas warna yang tidak sesuai dengan gambar (dikarenakan teknologi yang semakin canggih sehingga satu jenis warna terlihat seperti warna lainnya), dan manfaat suatu produk yang tidak sama dengan apa yang divisualisir oleh customer ketika akan melakukan suatu pembelian.

Di kasus lainnya, dahulu pada awal-awal munculnya bisnis onlinesekitar tiga tahun yang lalu-banyak bermunculan usaha-usaha konveksian baru yang bertugas untuk membuat produk yang serupa dengan gambar dari suatu produk tertentu. Jadi, ketika ada gambar dari suatu produk dengan kualitas yang tinggi dan best seller, konveksian tersebut langsung akan memplagiasi model yang ada dengan menggunakan bahan yang lebih murah dan akhirnya bisa menjual produk jadinya dengan harga yang sangat murah. Dikarenakan transaksi hanya menggunakan gambar, maka ketika terjadi transaksi, banyak konsumen dirugikan karena bayangan mereka, barang yang dibeli berkualitas sangat bagus sesuai dengan foto yang ditampilkan, akan tetapi setelah transaksi berlaku, barang yang datang ke alamat masing-masing konsumen adalah barang tiruannya saja dengan kualitas yang sungguh sangat buruk.

Penjualan dalam bisnis online-dengan modus penipuan, dikarenakan kualitas yang tidak sesuai dengan gambar-kemudian lambat laun berkurang dengan sendirinya. Menurut penelitian yang dilakukan oleh Abdal Islam S. Imheed Moohmed, Nurdiana Binti Azizan, Mohd Zalisham Jali (2013), kepercayaan (trust) dan pastexperience dalam pembelian online merupakan motivasi utama bagi konsumen untuk melakukan pembelian secara online. Jadi, penggerak bagi niat pembelian para konsumen di dalam bisnis ini adalah sesuatu yang untouchable, yaitu kredibilitas para penjualnya yang bisa dibuktikan dengan produk dan layanan yang dibeli oleh konsumen karena konsumen akan melakukan pembelian berulang ketika mereka puas dan begitu juga perlakuan sebaliknya ketika mereka tidak puas..$^{5}$ Jadi, pelaku bisnis online yang bertahan di papan atas adalah mereka yang

mungkin dikembalikan lagi. Di sini akan ada dua ongkos kirim yang hangus dikarenakan pembelakuan khiyâr.

5 Abdal Islam S. Imheed Moohmed, et al. The Impact of Trust and Past Experience on Intention to Purchase in E-Commerce (t.t.: t.p., 2013). 
memiliki integritas yang tinggi karena bisnis ini lebih didominasi oleh aspek kepercayaan satu sama lainnya.

Penelitian lainnya menyebutkan bahwa ada enam faktor yang merupakan penentu seseorang untuk melakukan pembelian dengan cara online, keenam hal tersebut adalah 1) persepsi akan keterlibatan (perceived enjoyment), 2) kepercayaan (trust), 3) persepsi akan kemanfaatan (perceived usefulness), 4) reputasi yang kokoh dari perusahaan (firm reputation), 5) pengaruh sosial (social influence), dan 6) persepsi akan risiko (perceived risk). ${ }^{6}$ Persepsi akan keterlibatan bisa meyakinkan konsumen bahwa ia benar-benar menginginkan barang tersebut, akan tetapi persepsi itu kemudian bergeser kepada persepsi akan nilai manfaat suatu barang. Apabila pelanggan merasakan adanya suatu ketertarikan dan manfaat pada suatu barang, maka akan muncul pengaruh sosial dan persepsi akan risiko yang digerakkan oleh unsur kepercayaan dan reputasi yang kokoh dari sebuah perusahaan.

Di kesempatan lainnya, Dato Norraesah Mohamed ${ }^{7}$ mengimbau sejumlah pengusaha dari kalangan UMKM untuk mengembangkan bisnis online-nya dengan menggunakan etika karena faktor tersebut memegang peranan penting bagi pasar. Etika menjadi salah satu kunci perluasan bisnis UMKM terutama di dunia online. Etika tersebut dapat diterapkan saat pengusaha UMKM berdagang dengan baik dalam penyediaan produk maupun tata cara pemasaran mereka. Ia berharap pelaku bisnis online tidak melakukan suatu tindakan yang bisa mengurangi kepercayaan pelanggan mereka. ${ }^{8}$ Ketika salah satu penjual online terkena record yang buruk, maka ketahanan bisnis ini akan rentan terhadap kerugian, sehingga tidak bisa dipungkiri jika pernah ditemukan sebuah kasus di lapangan, yaitu salah satu pemain bisnis online terkena klaim yang tidak baik terkait dengan penipuan karena, misalnya, memesan ponsel selular akan tetapi yang datang kepada

\footnotetext{
6 Hossein Rezaee Dolat Abadi, Seyede Nasim Amirosadat Hafshejani, Faeze Kermani Zadeh, “Considering Factors that Affect Users' Online Purchase Intention with Using Structural Equation Modeling”, Interdisciplinary Journal of Contemporary Research in Business, Vol. 3, No. 8 (2011), 1-9.

7 Dato Norraesah Mohamed adalah chairman World Islamic Economic Forum (WIEF). Beliau mengungkapkan beberapa pernyataan tersebut saat menutup "The 2nd Regional WIEF Online Marketing Workshop" yang diselenggarakan WIFE bekerjasama dengan Ikatan Wanita Pengusaha Indonesia (IWAPI) serta Kamar Dagang dan Industri (KADIN) di Hotel Somerset Surabaya.

8 Ayu Citra Sukma Rahayu, "WIEF Imbau UMKM Kembangkan Bisnis Online Beretika", dalam www.antarajatim.com (diakses 8 Februari 2015).
} 
pelanggan adalah sabun mandi. Setelah diselidiki, berita dan kejadian yang ada adalah upaya dari pesaingnya untuk menjatuhkan kredibilitas toko online tersebut agar pelanggannya beralih kepada pesaing tersebut.

Dari beberapa pemaparan di atas, beberapa penjual dengan sistem online yang memiliki produk dengan kualitas buruk bisa dipastikan semakin lama akan semakin tidak memiliki pembeli yang loyal dan pada akhirnya banyak sekali produk-produk unggulan yang mewarnai penjualan online. Walaupun pembelian dilakukan dengan cara dropshiping pembeli sudah bisa mempelajari kualitas barangnya terlebih dahulu karena beberapa merk terkenal pun saat ini sudah memasarkan produk-produk mereka dengan cara online dan dropshiping.

\section{Sumbangsih Jual beli Online dan Sistem Dropship terhadap Pemberdayaan Wirausahawan Perempuan}

Baru-baru ini Presiden Joko Widodo meminta Kepala Badan Ekonomi Kreatif (BEK) Triawan Munaf untuk menjaga pertumbuhan bisnis online di Indonesia. Jokowi menilai jika dikelola dan dilindungi dengan lebih baik, bisnis online bisa menjadi alternatif sistem pemasaran produk-produk Indonesia. Namun lebih penting lagi, Jokowi juga meminta Triawan untuk melindungi bisnis online dari akuisisi investor asing. Triawan mengatakan, dirinya sepakat dengan Jokowi yang ingin agar bisnis online di Indonesia menjadi semakin besar dan menjadi penyeimbang yang cukup signifikan dalam menambah pendapatan negara. ${ }^{9}$ Di beberapa media massa, bisnis online terbukti mampu menciptakan beberapa industri kreatif yang sebelumnya industri tersebut memiliki omzet yang relatif kecil karena dilakukan dengan cara yang konvensional, setelah strategi pemasaran diubah dengan menggunakan online, maka omzet pun bertambah.

Di kesempatan lainnya, pada tahun 2013, Telkom (PT Telekomunikasi Indonesia Tbk) telah sukses menghubungkan UMKM dengan jaringan internet kepada 5.000 UMKM. Program yang diberi nama IndiPreneur ini diikuti dengan roadshow ke 10 kota besar di Indonesia, antara lain Medan, Palembang, Jakarta, Bandung, Semarang, Yogyakarta, Banjarmasin, Makassar, Bali, dan Surabaya. Di dalamnya juga ada program coaching, clinic, workshop, dan lain sebagainya. Menurut Direktur Entreprise dan Wholesale Telkom, Muhammad Awaluddin, pihaknya telah menganggarkan dana

9 http://www.cnnindonesia.com/ekonomi/20150127092012-92-27579/jokowi ingin-bisnis-online-indonesia-jadi-pemain-kelas-dunia/(diakses 6 Januari 2015). 
operasional expenditure (Opex) sekitar Rp 10 miliar. Sementara belanja modal atau capital expenditure (Capex) sebanyak Rp15 miliar-Rp20 miliar dan masuk Capex sampai 2017.10

Dari sisi supply, potensi demand yang sangat besar dari aktivitas perdagangan online memunculkan para penjual dan produsen dadakan. Beberapa kalangan berbondong-bondong untuk menjadi penjual, pemasar dan/atau produsen yang memasarkan produk mereka dengan cara online. Hal ini memunculkan para wirausahawan baru yang lambat laun cepat membesar karena pengaruh penjualan online yang relatif cepat. Terbukti banyak wirausahawan baru, yang awalnya hanya mengandalkan penjualannya dengan cara online, kemudian secara bertahap bisa membangun toko offline-nya. Transaksi yang berkembang tidak secara nyata biasa terjadi melalui sistem elektronik seperti internet yang biasa dikenali dengan e-commerce. ${ }^{11}$ Sebenarnya bisnis online dengan skala kecil yang menggunakan sistem dropship sangat potensial untuk membuka peluang kerja baru. Terlebih bukan hal yang rahasia apabila pelaku bisnis online banyak didominasi oleh ibu-ibu rumah tangga karena waktunya yang sangat fleksibel dan modalnya yang relatif kecil. Ini merupakan potensi yang baik untuk menciptakan lapangan kerja baru yang cenderung mengasyikkan. ${ }^{12}$ Penjualan melalui e-commerce bisa mendongkrak omzet mereka karena tidak memerlukan jam untuk berjualan, transaksi bisa dilakukan 24 jam nonstop, sehingga pelanggan lebih leluasa memilih berbagai macam produk dan mengomparasikan harganya dari banyak vendor. ${ }^{13}$

Dari hasil pengumpulan data dan observasi dalam penelitian yang dilakukan oleh Fauzia (2015) dan telah dipresentasikan di Marketing Festival STIE Perbanas Surabaya, didapati adanya trend baru, yaitu munculnya wirausahawan perempuan dari kalangan ibu rumah tangga. Para ibu rumah tangga tersebut yang awalnya hanya konsumtif karena hanya berperan membelanjakan pendapatan dari para suami, saat ini bergeser menjadi sosok yang produktif karena mulai berbondongbondong untuk berwirausaha. Hal ini bukan tanpa sebab karena peranan internet menjadi salah satu sebab merebaknya wirausahawan baru yang sebagian besar adalah perempuan. Ibu rumah tangga memiliki segudang rutinitas dalam kesehariannya tetapi ada saat-saat

10 Lihat http://bisnis.liputan6.com/read/509191/baru-5000-umkm-yang-melekinternet (diakses 8 Februari 2015).

${ }^{11}$ Fauzia, Pemanfaatan E-Commerce dan M-Commerce, 2.

${ }^{12}$ Fauzia, Transcendental Trust, 4.

${ }^{13}$ Fauzia, Pemanfaatan E-Commerce dan M-Commerce, 2. 
tertentu dalam satu hari mereka sudah keluar dari rutinitas tersebut. Di saat suami dan anak-anak mereka berangkat bekerja, pekerjaan rumah sudah terselesaikan dengan baik, mereka pun memiliki kebebasan waktu untuk bisa berselancar di internet. Awalnya mereka menjadi pelanggan e-commerce dengan menjadi konsumen di berbagai macam produk, mayoritas woman fashion. Akan tetapi lambat laun mereka pun menjadi pelaku e-commerce dengan cara dropship dan kemudian berkembang dengan mengumpulkan stok barang di rumah masing-masing. Selain dari kalangan ibu rumah tangga, banyak juga pelaku wirausahawan perempuan yang lahir dari kampus-kampus negeri maupun swasta. Khusus untuk mahasiswi pelaku bisnis online, mayoritas di antara mereka fokus pada penjualan woman fashion, ataupun mereka menjadi tenaga pemasar ketika ada kerabat mereka yang menjadi produsen makanan ringan, dan beberapa produk lainnya. ${ }^{14}$

Beberapa penelitian menyebutkan bahwa bahwa e-commerce juga menekan biaya operasional (operating cost) dan bahkan bisa menekan modal karena penjual retail yang baru belajar berjualan tidak harus mengumpulkan stok banyak barang. Mereka hanya mendapatkan gambar-gambar barang dari supplier ataupun agennya. Sistem ini dinamakan dengan dropship. Jadi, ini merupakan peluang untuk pembelajaran bisnis bagi mereka yang ingin menjadi wirausahawan tetapi masih diliputi keraguan khususnya yang berkaitan dengan permodalan. Bagi konsumen, e-commerce juga menekan biaya-biaya yang harus dikeluarkan ketika mereka berbelanja dengan sistem yang konvensional. Konsumen bisa melakukan transaksi setiap saat, dan setiap waktu. Mereka bisa mengakses informasi dengan baik sehingga langsung bisa mengomparasikan harga barang. Ini berimplikasi pada adanya peluang bagi konsumen untuk bisa mendapatkan barang yang bagus dengan harga yang murah, namun tentu memerlukan keahlian untuk menjadi konsumen yang cerdas, sebab jika konsumen tidak berhati-hati memilih dan memilah, maka bisa jadi mereka akan mendapatkan barang yang tidak berkualitas dengan harga yang tinggi. ${ }^{15}$

\section{Beberapa Pandangan Ahli Fiqh tentang Dropship}

Efek dari perkembangan online business yang sangat luar biasa ini, maka akan sangat mudah dijumpai penjual online 'dadakan' yang

\footnotetext{
14 Ibid., 14-15.

${ }^{15}$ Ibid., 18.
} 
berusaha mengadu peruntungan walaupun hanya berjualan lewat gambar-gambar. Dengan sistem dropship mereka melayani customer mereka walau penjual belum pernah mengetahui kualitas barang selain hanya versi gambarnya, sehingga banyak bermunculan droship pararel karena ada beberapa tingkat penjualan yang menjual barang hanya bermodalkan gambar. ${ }^{16}$ Banyak di antara ahli fiqh yang ketika mendapatkan beberapa pertanyaan dari masyarakat mengenai hukum dropship, mereka menjawab bahwa dropship haram. Hal ini dikarenakan dalam akad ini pelaku dropshiping menjual barang yang belum dimilikinya. Jawaban ini merupakan jawaban yang jamak diungkapkan oleh ahli fiqh di Indonesia.

Ketika pelaku dropship dikenali sebagai seorang penjual, maka sudah jelas sistem ini mempunyai banyak kekurangan yang bisa menyebabkan keharaman. Ada beberapa syarat dalam jual beli yang harus dipenuhi, yaitu: 1) barang yang dijual harus dimiliki terlebih dahulu agar tidak masuk ke area jual beli sesuatu yang tidak ada, ataupun jual beli sesuatu yang tidak bisa diserahterimakan agar tidak masuk dalam kategori gharar, ${ }^{17}$ 2) jual beli sesuatu harus diketahui harganya dengan baik; dan 3) jual beli harus diketahui klasifikasi barangnya dengan baik. ${ }^{18}$ Dalam sebuah Hadîth disebutkan yang maknanya adalah: Dari 'Amr b. Shu'ayb, dari ayahnya, dari kakeknya, bahwa bersabda: Tidak dibalalkan penjualan yang bukan milik kalian dan tidak pula dibalalkan keuntungan yang tidak terjamin..$^{19}$ Dalam Hadîth yang lain juga disebutkan yang maknanya adalah: "Dari Ibn 'Abbâs mengatakan, Rasulullah membeli barang-barang dari kafilah yang datang ke Madinah, lalu mendapat keuntungan (dari menjualnya) beberapa awqiyah. Beliau membagi-bagikan keuntungan itu untuk janda-janda 'Abd al-Mutallib. Kemudian Beliau bersabda: Aku tidak membeli barang, kecuali Aku mengetahui harganya. ${ }^{20}$ Lebih lanjut,

\footnotetext{
${ }^{16}$ Fauzia, Transcendental Trust, 4.

17 Gharar adalah adanya ketidakjelasan barang yang akan dijual dan adanya skeptis dalam mendapatkan salah satu barang pengganti dalam jual beli. Lebih jauh lihat Samîrah Sayyid Sulaymân, al-Wajî̀ fì al-Aḅkâm al-Mu'âmalâh (Kairo: Al-Azhar University Press, 2002), 33.

18 Wahbah al-Zuhaylî, al-Fiqh al-Islâmî wa Adillatuh, Vol. 4 (Damaskus: Dâr al-Fikr, 2010), 75-81.

${ }^{19}$ H.R. Ibn Mâjah dan Ahmad b. Ḥanbal dalam Aḥmad b. Ḥanbal, al-Musnad li alImâm bin Hanbal (164-241), taḥî̀q 'Abd Allâh Muhammad al-Darwish (t.t.: Dâr alFikr, 1991).

${ }^{20}$ H.R. Ahmad b. Ḥanbal dalam bin Hạbal, Al-Musnad li al-Imâm.
} 
syarat sahnya jual beli yang berkenaan dengan ma'qûd alayh (komoditi yang ditransaksikan) adalah: 1) komoditas yang ditransaksikan harus ada saat transaksi, 2) komoditi berupa barang/jasa yang memiliki manfaat, 3) komoditi yang ditransaksikan merupakan hak penjual, dan 4) komoditi yang ditransaksikan harus diketahui secara jelas oleh muta ấidayn (dua pihak yang bertransaksi). ${ }^{21}$

Adapun klasifikasi jual beli secara umum adalah jual beli yang benar (sahîh), jual beli yang batil (bâtil) dan jual beli yang rusak (fâsid). Jual beli sahîh dimaknai dengan jual beli yang telah memenuhi syarat dan rukun akad. Adanya penjual, pembeli, kesepakatan pembelian, barang, harga dan bertujuan untuk kemaslahatan. Adapun jual beli yang tidak benar (ghayr sabîh) adalah yang tidak terpenuhi syarat dan rukun akadnya. Jual beli tidak benar terbagi menjadi jual beli yang batil (al-bay' al-bâtil) dan jual beli yang rusak (al-bay' al-fâsid). Adapun yang termasuk dalam jual beli yang batil menurut Imam Hanafî, di antaranya adalah 1) jual beli yang tidak ada barangnya, 2) jual beli sesuatu yang tidak mungkin diadakan, 3) jual beli gharar, yaitu jual beli yang mengandung unsur ketidakjelasan yang terjadi pada salah satu dari penjual ataupun pembeli, ${ }^{22}$ dan 4) jual beli sesuatu yang najis dan menajiskan. ${ }^{23}$ Jual beli yang dikategorikan dalam jual beli yang rusak menurut Imam Abû Hanîfah adalah 1) jual beli sesuatu yang tidak diketahui (bay" al-majbûh), yaitu ketidaktahuan dalam hal barang, harga, waktu penyerahan dan syarat-syarat dokumentasi barang (wasầil altawthî ), 2) jual beli dengan syarat, misalnya seorang penjual berkata: "aku menjual rumah ini kepadamu, dengan syarat engkau tidak boleh menjual rumah ini kepada orang lain", 3) jual beli sesuatu yang belum dilihat, diperbolehkan jika ada gambar, akan tetapi Imam Abû Ḥanîfah mensyaratkan adanya khiyâr (penentuan pembelian atau

\footnotetext{
21 'Abd Allâh b. Muhammad al-Tayyâr, 'Abd Allâh b. Muhammad al-Mutlaq, Muhammad b. Ibrâhîm, Ensiklopedi Fikih Muamalah dalam Pandangan 4 Madžhab, terj. Miftahul Khairi (Yogyakarta: Maktabah al-Hanif, 2004), 6-10.

22 Adapun dalam pembahasan tentang gharar yasîr (gharar yang kapasitasnya sedikit), pengikut mazhab Mâlikîyah dan Hanâbilah memperbolehkannya, yaitu gharar yasîr yang berhubungan dengan sesuatu yang sangat primer. Contoh gharar yasîr menurut mazhab Mâlikîyah adalah jual beli kacang yang masih ada kulitnya. Jika jual beli harus dilakukan dengan membuka kulitnya, maka akan menyusahkan pihak penjual dan pembeli.

23 Seperti jual beli minuman memabukkan, babi, bangkai dan darah karena barangbarang tersebut bukan termasuk kategori harta benda (mâl) dalam Islam dan ini dilarang.
} 
pembatalan) ketika barang telah ada. Imam Mâlik menyatakan bahwa ketika ciri-ciri barang yang dipesan ada pada barang tersebut, maka jual beli harus berlangsung. Akan tetapi jika barang yang ada tidak sesuai dengan gambar barang atau ciri-cirinya pada saat akad, maka pembeli mempunyai pilihan untuk melanjutkan jual beli atau membatalkannya, 4) jual beli aynah, yaitu menurut bahasa berarti meminjam atau berhutang. ${ }^{24}$

Jual beli yang rusak dan batil menurut mazhab Mâlikî adalah mencakup lima aspek, yaitu: 1) yang berkaitan dengan dua belah pihak yang melakukan akad (âqidayn), 2) yang berkaitan dengan harga, 3) yang berkaitan dengan gharar, 4) yang berkaitan dengan pembahasan tentang ribâ, dan 5) yang berkaitan dengan jual beli yang dilarang, dan secara keseluruhan mencakup 10 macam praktik jual beli, misalnya adalah jual beli makanan sebelum dimiliki, jual beli aynah, jual beli urbûn, jual beli bâdir li al-bâdy, jual beli barang yang telah diperjual belikan, jual beli pada masa salat Jumat, jual beli dengan syarat (bay' althanâyâ), dan lain sebagainya. ${ }^{25}$

Dari beberapa keterangan di atas, jika pelaku dropshiping menjual barang berdasarkan gambar yang belum menjadi miliknya (karena masih ada di tangan suppliemya) berdasarkan akad jual beli, maka hal ini adalah dilarang. Alasannya adalah tidak sesuai beberapa rukun dan syarat jual beli di atas. Namun harus dilihat kembali bahwa khazanah fiqh Islam sangat kaya akan akad-akad yang sesuai dengan aktivitas dropship ini. Jadi dropship yang berlaku selama ini tidak hanya bisa dibatasi dengan akad jual beli. Ada tawaran menarik untuk memposisikan para pelaku dropship menjadi seorang wakîl ataupun simsâr.

\section{Akad Wakâlah dan Samsarah sebagai Solusi}

Definisi wakâlah secara etimologis adalah tawkîl, yaitu menyerahkan/mewakilkan dan menjaga. Makna wakâlah secara terminologis adalah mewakilkan yang dilakukan oleh orang yang memiliki hak tasarruf kepada orang yang juga memiliki hak tasarruf tentang sesuatu yang boleh diwakilkan. Dasar dari al-Qur'ân adalah Q.S. al-Kahf [18]:19, ${ }^{26}$ yaitu:

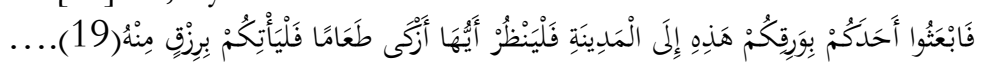

${ }^{24}$ Ika Yunia Fauzia dan Abdul Kadir Riyadi, Prinsip Dasar Ekonomi Islam Perspektif Maqashid al-Shariah (Jakarta: Prenada, 2014), 244-252.

${ }^{25}$ Ibid., 253.

26 al-Ṭayyâr, et al., Ensiklopedi Fikì Muamalah, 251, 
"Maka suruhlah salah seorang di antara kamu pergi ke kota dengan membawa uang perakmu ini, dan hendaklah dia lihat manakah makanan yang lebih baik, lalu hendaklah dia membawa makanan itu untukmu".

Ayat lainnya dalam surah al-Nisâ' [4]: 35 juga menjadi dasar disyariatkannya wakâlah yang artinya: Dan jika kamu khawatirkan ada persengketaan antara keduanya, maka kirimlah seorang hakam (wakîl) dari keluarga laki-laki dan seorang hakam dari keluarga perempuan. Di dalam Q.S. Yûsuf [12]: 93 juga disebutkan tentang wakâlah yang artinya: "Pergilah kamu dengan membawa baju gamisku ini". ${ }^{27}$

Dasar dari Hadîth adalah Rasulullah pernah mewakilkan kepada 'Urwah b. Abî al-Jad al-Bariqîi ${ }^{28}$ dan Hâkim b. Hazm ${ }^{29}$ untuk membeli domba. Di dalam kitab al-Mughnî dinyatakan bahwa ulama telah sepakat memperbolehkan wakâlah atas dasar ijmâr. ${ }^{30}$ Menurut Qiyâs bahwa kebutuhan manusia menuntut adanya wakâlah karena tidak setiap hari manusia mampu menyelesaikan urusannya sendiri secara langsung, sehingga ia membutuhkan orang lain untuk menggantikannya sebagai wakil. . $^{31}$

Rukun dan syarat wakâlah ada empat, yaitu: muwakkil (orang yang mewakilkan), wakîl (orang yang mewakili), muwakkal fîh (objek yang

\footnotetext{
${ }^{27}$ Kedua ayat ini merupakan syariat umat terdahulu (shar man qablanâ), dan menurut pendapat yang benar, isi ayat bukan merupakan sharî‘ah kita sekalipun hal itu dicantumkan dalam shari`ah kita. Lihat Mustafa Dib al-Bugha, Buku Pintar Transaksi Syariah, terj. Fakhri Ghafur (Jakarta: Penerbit Hikmah/PT Mizan Publika, 2010), 316.

28 Makna Hadîthnya adalah diriwayatkan dari 'Urwah (Ibn Abî al-Ja'd al-Bârûqî̀) yang mengatakan bahwa Rasulullah memberinya satu dinar untuk membeli seekor hewan kurban atau seekor domba. Lalu ia membeli dua ekor domba dan menjual satu ekor dengan harga satu dinar. Ia datang menemui Beliau dengan membawa satu domba dan satu dinar. Beliau mendoakan untuk keberkahan jual belinya. Sekiranya ia membeli debu (perumpamaan), ia pasti akan beruntung. (H.R. Abû Dâwud) dalam Abû Dâwud al-Sijistânî, Sunan Ab̂̉ Dâwud (Kairo: t.p., 1280).

29 Makna Ḥadîthnya adalah dari Hakîm b. Hazam bahwa Rasulullah mengirim bersamanya satu dinar untuk membeli satu ekor hewan kurban untuk Beliau. Lalu ia membelikannya dengan harga satu dinar dan menjualnya dengan harga dua dinar. Lalu ia kembali dengan membelikan hewan kurban untuk beliau seharga satu dinar dan memberikan satu dinar lainnya kepada Rasul. Lalu uang itu disedekahkan oleh Rasul dan Beliau mendoakannya semoga mendapat keberkahan dalam perdagangan. Lihat Abû Dâwud, Sunan Abû Dâwud.

${ }^{30}$ Ibn Qudâmah, al-Mughnî, Vol. 7 (Riyad: Maktabat al-Riyâḍ al-Hadîthah, 620 H), 196.

31 Ibid.
} 
diwakilkan) dan sîghat (îjâb dan qabû̉. ${ }^{32}$ Menurut Imam Mâlik dan Shâfîî, pemberian kuasa dari muwakekil boleh ketika orang itu tidak ada halangan. ${ }^{33}$ Kemudian syarat wakîl adalah tidak dilarang oleh shara untuk melakukan tindakan (perbuatan) terhadap sesuatu yang dikuasakan kepadanya. Syarat perkara/objek yang dikuasakan (altawkîi) adalah perkara tersebut dapat digantikan oleh orang lain, seperti jual beli, pemindahan hutang kepada orang lain, pembatalanpembatalan, serikat dagang, pemberian kuasa, penukaran mata uang, pemberian gaji, akad bagi hasil (al-musâqât), perdamaian dan lain sebagainya. Sifat pemberian kuasa adalah akad yang menjadi wajib dengan adanya $\hat{y j a} b$ dan qabûl, seperti halnya akad-akad yang lain.

Wakâlah bukan akad yang mengikat melainkan akad yang jầiz. (artinya bisa dibubarkan). Imam Mâlik berpendapat bahwa pemberian kuasa itu ada dua macam, yaitu bersifat umum dan khusus, bersifat umum ialah pemberian kuasa yang berlaku secara umum tanpa menyebutkan satu-persatu perkaranya, sebab apabila disebutkan, maka sifat-sifat keumuman dan penyerahannya tidak dapat digunakan. Sedangkan Imam Shâfîi berpendapat bahwa pemberian kuasa tidak boleh bersifat umum, karena mengandung kesamaran, yang diperbolehkan adalah yang disebutkan, dibatasi dan dinyatakan (perkaranya). ${ }^{34}$ Wakâlah boleh dilakukan berdasarkan tulisan dan surat. ${ }^{35}$ Menurut Wahbah al-Zuhaylî, objek wakâlah adalah sesuatu yang memiliki identitas yang jelas dan milik sah dari muwakekil. ${ }^{36}$

Imam Mâlik berpendapat bahwa orang yang diberi kuasa itu tidak boleh menjual kecuali berdasarkan harga pasar, secara tunai dan dengan mata uang negeri itu. Jika ia menjual dengan harga tangguh atau tidak berdasarkan harga pasar, menurut Imam Mâlik, tidak boleh. Akan tetapi Imam Abû Ḥanifah menyatakan adanya pemisahan untuk

\footnotetext{
32 Di beberapa referensi disebutkan rukun saja, dan di beberapa referensi disebutkan rukun dan syarat. Beberapa yang menyebutkan rukun saja di antaranya adalah alThayyar, et al., Ensiklopedi Fikib Muamalah, 252; Ibn Rushd, Bidayat al-Mujtabid, terj. A.A. Abdurrahman dan A. Haris Abdullah, Vol. 3 (Semarang: CV. Asy-Syifa, 1990), 359; dan yang menuliskan rukun dan syarat adalah Dib al-Bugha, Buku Pintar, 317; Fathurrahman Djamil, Penerapan Hukum Perjanjian dalam Transaksi di Lembaga Keuangan Shariah (Jakarta: Sinar Grafika, 2012), 191-192.

33 Dikarenakan Imam Abû Hanîfah berpendapat bahwa pemberian kekuasaan dari orang yang sehat dan tidak bepergian itu tidak boleh. Lihat Ibn Rushd, Bidayat alMujtabid, 369.

34 Ibid., 371.

${ }_{35}$ Dib al-Bugha, Buku Pintar, 338.

${ }^{36}$ al-Zuhaylî, al-Fiqh al-Islâmî, 748.
} 
penjualan dan pembelian pada barang tertentu. Beliau berpendapat bahwa dalam ikhwal penjualan diperbolehkan menjual dengan pembayaran tempo. Jika seseorang diberikan kuasa untuk pembelian suatu barang, maka ia tidak boleh membeli dengan harga tempo dan tidak sesuai dengan harga pasar. ${ }^{37}$

Wakâlah bisa dengan fee (ujr/ja't) ataupun tidak dengan fee karena Rasulullah juga melakukan beberapa akad tawkîl. Wakâlah adalah akad yang jầ y yang dibolehkan bagi seorang wakîl untuk mengambil fee atau bayaran dari akad tersebut. Jikalau wakalah tidak dengan fee, maka disebut wakîl. Akan tetapi jikalau pemberian fee ataupun bonus maka dihukumi dengan hukum al-ijârah. Seorang wakîl bisa memperoleh bonusnya ketika telah selesai mengerjakan perkara yang diwakilinya. Ketika seorang wakîl mewakili untuk urusan penjualan atau pembelian, maka ia telah berhak mendapatkan bonus walaupun uang hasil penjualan belum dimiliki (lam yaqbid al-thaman). ${ }^{38}$

Perwakilan dalam hal jual beli, menurut al-Zuhaylî, bisa saja terjadi secara mutlak (mutlaq al-tasarruf) dan bisa terjadi secara khusus (muqayyad al-tasarruf). Ketika penjualan dilakukan secara khusus, maka harus disertai dengan beberapa aturan pengkhususan, dan jika klasifikasi kekhusususan tersebut tidak ditaati oleh wakill, maka akad wakâlah tidak sah. Misalnya munakkil mensyaratkan penjualan kebun seharga 100 juta, dan wakîl menjualnya dengan harga 90 juta. Wakâlah tidak sah karena tidak sesuai dengan kesepakatan khusus yang menjurus kepada kerugian. Namun apabila wakîl menjual dengan harga 110 juta, maka akad sah karena walaupun harga 110 juta tidak sesuai dengan ketentuan khusus tadi (muqayyad al-tasarruf), akan tetapi hal tersebut diperbolehkan karena menjurus kepada keuntungan (muwakki). Begitu pula akad wakâlah ini tidak sah, jika muwakkil mensyaratkan jual beli dilakukan secara cash, akan tetapi ternyata wakîl menjual dengan kredit, begitu juga sebaliknya. ${ }^{39}$

Ketika akad wakâlah dilakukan secara umum (mutlaq al-tasarruf), maka menurut Imam Abû Hanîfah wakîl bisa melakukan transaksi secara mutlak pula, dalam artian, wakîl bisa menjual dengan harga yang ia tentukan, secara cash atau tempo. Abû Haninifah berpedoman pada dalil bahwa ketentuan asal dari lafal mutlak adalah berjalan pada kemutlakannya (al-asl fî al-lafz al-mutlaq an yajrî ala itlâqih). Begitu juga

${ }^{37}$ Ibn Rushd, Bidayat al-Mujtahid, 375.

${ }^{38}$ al-Zuhaylî, al-Fiqh al-Islâmî, 745-756.

39 Ibid., 773. 
ketika sudah disepakati kemutlakan akad wakâlah sebelumnya, maka 'urf pun tidak bisa dijadikan sandaran. Kemutlakan tersebut tidak bisa dipahami secara muqayyad dengan batasan-batasan tertentu. ${ }^{40}$ Sedangkan bahasan tentang samsarah, beberapa ahli fiqh banyak membahas tentang samsarah, akan tetapi tidak banyak yang meletakkan bahasan ini dalam satu bahasan tersendiri. Bahasan tentang hal ini dimasukkan dalam kategori bâb al-ijârah (sewa menyewa) dan bâb albay" (jual beli).

Adapun makna dari samsarah secara bahasa adalah mufrad dari simsâr, yaitu perantara di antara penjual dan pembeli untuk menyempurnakan jual beli. Simsâr menunjukkan kepada pembeli dan penjual suatu produk/jasa. Makna samsarah secara terminologis, menurut Imam Abû Ḥanifah, adalah suatu nama yang diperuntukkan bagi seseorang yang bekerja untuk orang lain dengan suatu upah yang berkaitan dengan penjualan dan pembelian. Menurut Imam Mâlik, makna samsarah adalah orang yang berputar-putar di dalam pasar dengan suatu produk yang mengakibatkan bertambah nilai produk tersebut. ${ }^{41}$ Samsarab adalah suatu bantuan yang dilakukan oleh seseorang untuk saudaranya dengan suatu upah tertentu untuk pekerjaan yang telah dilakukan.

Adapun dalil yang terkait dengan pensyariatan samsarah adalah seperti yang tertera dalam al-Qur'ân surah al-Mâidah [5]: 2 yang berbunyi:

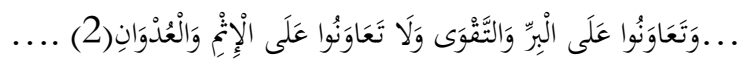

... dan saling tolong menolonglah kalian dalam kebaikan, dan janganlah saling tolong menolong dalam dosa dan permusuhan.

Di dalam sebuah Hadîth, disebutkan tentang samsarah yang artinya: "Dari Qays b. Abî Gharzah mengatakan: Kami biasa memperjualbelikan barang-barang, dan kami menamakan diri kami broker (simsâr) dan masyarakat juga menamakan kami broker. Lalu Rasulullah datang menemui kami, dan beliau menamakan kami dengan nama yang lebih baik dari yang kami berikan pada diri kami. Beliau bersabda: "Wahai para tukang jual (tujjâr), jual belimu diperkuat

\footnotetext{
40 Ibid., 774-775.

${ }^{41}$ Tim Dosen Penyusun Jurusan Fiqh Perbandingan, Qadâyâ Fiqhîyah Mu'âsirah, Vol. 4 (Kairo: Diktat Kuliah Universitas al-Azhar, 2003), 130.
} 
dengan sumpah dan kepalsuan, karena itu selingilah jual belimu dengan sedekah". ${ }^{42}$

Dalam hadîth di atas, Rasulullah tidak mengingkari pekerjaan yang dilakukan oleh simsâr tetapi Rasulullah menasehati dan memberikan nama kepada mereka dengan nama yang lebih baik. Para ulama juga tidak ada satupun yang melarang adanya praktik samsarah. Dikarenakan ini adalah perkara yang mubâh (diperbolehkan), maka ijmâ' ulama menyatakan bahwa samsarah adalah boleh. Perbedaan antara wakâlah dengan samsarah adalah bahwa akad wakâlah merupakan akad yang memperbolehkan wakîl untuk melakukan tasarruf ataupun transaksi sesukanya sesuai dengan instruksi dari muwakkil-nya, sedangkan seorang simsâr tidak menjual dan membeli, simsâr hanya menjadi perantara di antara penjual dan pembeli. Simsâr jugalah yang menunjukkan kepada manusia suatu produk/jasa dan harganya. Bisa jadi seseorang menggunakan tenaga seorang simsâr untuk membantunya bertransaksi. ${ }^{43}$

Beberapa syarat samsarah adalah: a) mengetahui pekerjaan yang diminta, b) cakap dalam melaksanakan pekerjaan, c) bekerja atas seizin yang memberikan wewenang, jika tanpa izin, maka tidak berlaku pekerjaannya, dan d) mempunyai attitude yang baik. Terkait dengan pengupahan untuk simsâr, harus diperhatikan bahwa pengupahan telah disepakati dan diketahui dari awal, ataupun pengupahan bisa jadi persentase tertentu pun semisal ujrat al-mithlì. Seorang simsâr tidak mendapatkan upah kecuali jika telah menyelesaikan pekerjaannya dengan baik. Ketika pekerjaan yang dilakukannya tidak berhasil, maka dia tidak akan mendapatkan apa-apa. ${ }^{44}$

Dalam bisnis online, aktivitas dropship yang telah menjadi tradisi saat ini sebenarnya bisa dijalankan dengan sistem wakâlah ataupun samsarah, tetapi tentu harus ada beberapa hal yang harus dibenahi, di antaranya dapat digambarkan berikut.

1. Seorang reseller sebelum melakukan dropship, ia harus menyatakan suatu akad kepada upline-nya (supplier atau agen atau distributornya), meminta izin untuk menjalankan usaha dengan sistem wakâlah atau samsarah. Ketika memilih akad wakâlah, maka harus disepakati dari

\footnotetext{
${ }^{42}$ Hạâth Riwayat al-Nasầî, Abû Dâûd, al-Tirmîdhî, Ibn Mâjah dan Ahmad b. Hanbal.

${ }^{43}$ Tim Dosen, Qadâyâ Fiqhîyah, 131-133.

${ }^{44}$ Ibid., 139-140.
} 
awal bahwa reseller yang menjualkan barang-barang upline-nya merupakan wakîl.

2. Seorang reseller yang melakukan dropship ada baiknya menyampaikan kepada customer bahwa dia adalah perwakilan dari upline-nya untuk mewakili menjualkan barang upline-nya.

3. Keuntungan yang diambil oleh pelaku dropship harus didiskusikan dengan upline-nya. Ketika mengacu kepada akad samsarah, maka keuntungan harus berupa pengupahan yang telah disepakati dan diketahui dari awal, ataupun pengupahan bisa jadi persentase tertentu pun semisal ujrat al-mithlî. Seorang simsâr tidak mendapatkan upah kecuali jika telah menyelesaikan pekerjaannya dengan baik. Misalnya harga barang Rp. 100.000, maka bisa jadi disepakati terlebih dahulu bahwa keuntungan berupa 10-20\% dari laba penjualan adalah upah yang akan dibayarkan, itupun ketika barang laku. Jadi, ketika pelaku dropship berhasil menjual barang tadi, misalnya, dengan laba 20\% (Rp. 120.000), maka sudah disepakati di depan bahwa 20\% tersebut adalah upah yang merupakan hak simsâr/dropshipper. Persentase tersebut adalah upah yang akan dibayar oleh upline/sâhib al-sil'ah (pemilik barang) kepada dropshipper.

4. Sistem pembayaran fee bagi aktivitas dropship ketika menggunakan akad wakâlah, menurut Wahbah al-Zuhaylî, bisa dengan fee (ajr) ataupun tidak dengan fee, karena Rasulullah juga melakukan beberapa akad tawkîl. Wakâlah adalah akad yang jầiz yang dibolehkan bagi seorang wakîl untuk mengambil fee atau bayaran dari akad tersebut. Jika wakâlah tidak dengan fee, maka disebut wakîl. Jika pemberian fee ataupun bonus, maka dihukumi dengan hukum al-ijârah. Seorang wakîl bisa memperoleh bonusnya ketika telah selesai mengerjakan perkara yang diwakilinya. Ketika seorang wakîl mewakili untuk urusan penjualan atau pembelian, maka ia telah berhak mendapatkan bonus walaupun uang hasil penjualan belum dimiliki (lam yaqbị al-thamân). ${ }^{45}$

5. Ketika akan melakukan akad wakâlah atau samsarah, maka jangan lupa untuk mempelajari dan memilih supplier yang benar-benar memiliki produk dengan kualitas yang bagus agar dalam pelaksanaan akad wakâlah dan samsarah bisa berhasil. Ketika konsumen puas dengan transaksi yang dilakukan, maka keberkahan akan selalu mengikuti akad ini, dan terlebih dari itu bonus (al-ja'),

${ }^{45}$ al-Zuhaylî, al-Fiqh al-Islâmî, 745-756. 
fee, upah, dan yang lain sebagainya akan selalu mengikuti pelaku dropship (wakîl dan simsâr) karena pembeli akan berkali-kali melakukan pembelian. Pembeli yang merasakan kepuasan dan manfaat dari barang yang telah dibelinya akan merekomendasikan perasaannya kepada orang lain.

\section{Penutup}

Islam sangat kaya dengan ajaran-ajarannya yang bermuara pada kemaslahatan manusia. Ketika ada suatu model transaksi terbaru dalam masyarakat, beberapa ahli fiqh mayoritas mengaitkan aktivitas tersebut dengan satu akad saja, yaitu 'aqd al-buy $\hat{u}^{\prime}$ (akad jual beli). Padahal semestinya sebuah transaksi bisa dikaitkan dengan beberapa akad lainnya yang memiliki bentuk yang sama. Keterbatasan pemakaian referensi juga merupakan salah satu sebab munculnya pengharaman yang secara tiba-tiba. Ketika merujuk kepada banyak referensi dan banyak mazhab akan bisa ditemukan bahwa hakikat dari mu'âmalât adalah satu kaidah, yaitu: al-asl fì al-mu'âmalâh al-ibâhah illâ an yadull dalîl 'alâ taḥrimihâ (segala sesuatu dalam aktivitas mu'âmalah adalah boleh kecuali ada dalil yang melarang).

\section{Daftar Rujukan}

Abadi, Hossein Rezaee Dolat., Hafshejani, Seyede Nasim Amirosadat., Zadeh, Faeze Kermani. "Considering Factors that Affect Users' Online Purchase Intention with Using Structural Equation Modeling", Interdisciplinary Journal of Contemporary Research in Business, Vol. 3, No. 8, 2011.

al-Bugha, Mustafa Dib. Buku Pintar Transaksi Syariah, terj. Fakhri Ghafur. Jakarta: Penerbit Hikmah/PT Mizan Publika, 2010.

al-Tayyâr, 'Abd Allâh b. Muhammad., al-Mutlaq, 'Abd Allâh b. Muhammad., Ibrâhîm, Muhammad b. Ensiklopedi Fikỉ Muamalah dalam Pandangan 4 Mad₹̧bab, terj. Miftahul Khairi. Yogyakarta: Maktabah al-Hanif, 2004.

Djamil, Fathurrahman. Penerapan Hukum Perjanjian dalam Transaksi di Lembaga Kenangan Shariah. Jakarta: Sinar Grafika, 2012.

Fauzia, Ika Yunia. Pemanfaatan E-Commerce dan M-Commerce dalam Bisnis di Kalangan Wirausahawan Perempuan. Surabaya: STIE Perbanas, 2015.

-----. Transcendental Trust dalam Bisnis Online di Kalangan Pengusaba Garment di Indonesia. Surabaya: Penelitian Internal STIE Perbanas, 2015. 
Fauzia, Ika Yunia., dan Riyadi, Abdul Kadir. Prinsip Dasar Ekonomi Islam Perspektif Maqashid al-Shariah. Jakarta: Prenada, 2014.

Http://www.cnnindonesia.com/ekonomi/20150127092012-92-

27579/jokowi -ingin-bisnis-online-indonesia-jadi-pemain-kelasdunia/diakses 6 Januari 2015.

Http:/ / bisnis.liputan6.com/read/509191/baru-5000-umkm-yangmelek-internet/diakses 8 Februari 2015.

Mâjah, H.R. Ibn dan Ḥanbal, Aḥmad b. dalam Aḥmad b. Ḥanbal, AlMusnad li al-Imâm b. Hạbal (164-241), taḥ̂îq 'Abd Allâh Muhammad al-Darwish. t.t.: Dâr al-Fikr, 1991.

Moohmed, Abdal Islam S. Imheed et al. The Impact of Trust and Past Experience on Intention to Purchase in E-Commerce. t.t.: t.p., 2013.

Penyusun Jurusan Fiqh Perbandingan, Tim Dosen. Qadâyâ Fiqhîyah Mu'âsirah, Vol. 4. Kairo: Diktat Kuliah Universitas al-Azhar, 2003. Qudâmah, Ibn. al-Mughnî, Vol. 7. Riyad: Maktabat al-Riyâd alHadîthah, $620 \mathrm{H}$.

Rahayu, Ayu Citra Sukma. "WIEF Imbau UMKM Kembangkan

Bisnis Online Beretika", dalam www.antarajatim.com (diakses 8 Februari 2015.

Rushd, Ibn. Bidayat al-Mujtahid, terj. A.A. Abdurrahman dan A. Haris Abdullah, Vol. 3. Semarang: CV. Asy-Syifa, 1990.

Sijistânî (al), Abû Dâwud. Sunan Abû Dâwud. Kairo: t.p., 1280.

Sulaymân, Samîrah Sayyid. al-Wajî̀, fì al-Aḥkâm al-Mu'âmalâh. Kairo: Al-Azhar University Press, 2002.

Wahyudiyanta, Imam. "Dream Merchant: Cara Rakuten Online-kan UMKM di Surabaya", dalam http://news.detik.com/berita-jawatimur/3027217/dream-merchant-cara-rakuten-online-kan-umkmdi-surabaya/Diakses 8 Februari 2015.

Zuhaylî (al), Wahbah. al-Figh al-Islâmî wa Adillatuh, Vol. 4. Damaskus: Dâr al-Fikr, 2010. 